\title{
Isolation of complement-fragment-iC3b-binding proteins by affinity chromatography
}

\author{
The identification of p150,95 as an iC3b-binding protein
}

\author{
Kingsley J. MICKLEM* $\ddagger$ and Robert B. SIM $\dagger$ \\ *Department of Pharmacology, University of Oxford, South Parks Road, Oxford OX1 3QT, and †MRC Immunochemistry \\ Unit, Department of Biochemistry, University of Oxford, South Parks Road, Oxford OX1 3QU, U.K.
}

\begin{abstract}
The proteins from labelled human spleen membranes and polymorphonuclear leucocytes which bind to the iC3b fragment of complement component C3 were prepared by iC $3 b$-Sepharose chromatography in the presence of bivalent cations. Complement receptor type 3(CR3) was eluted from iC3b-Sepharose by removal of bivalent cations. Complement receptors type 1 and 2 (present in spleen but not in polymorphonuclear leucocytes) were sequentially eluted by an $\mathrm{NaCl}$ gradient. An additional protein of $M_{\mathrm{r}} 135000$ was eluted from $\mathrm{iC} 3 \mathrm{~b}-$ Sepharose under the same conditions as those used to elute CR3. Preabsorption of the starting material on an anti-(CR3 $\beta$-subunit) antibody column before iC $3 \mathrm{~b}$-Sepharose chromatography removed the $\alpha$ - and $\beta$-chains of CR3 and the $135000-M_{\mathrm{r}}$ protein. Preabsorption with $\mathrm{iC} 3 \mathrm{~b}-$ Sepharose before the anti(CR3 $\beta$-subunit) antibody column showed that iC3b binds CR3 and p150,95, the smallest member of the group of three homologous proteins that share the same $\beta$-subunit.
\end{abstract}

\section{INTRODUCTION}

Human leucocytes possess receptors for fragments of the third component of complement (C3) (Fearon \& Wong, 1983). These receptors are involved in the recognition of opsonins during phagocytosis (Ehlenberger \& Nussenzweig, 1971) and may modulate the immune response (Weigle et al., 1983).

After complement activation, C3 binds covalently to the activating surface as the $\mathrm{C} 3 \mathrm{~b}$ fragment $\left(M_{\mathrm{r}} 178000\right)$ (Law \& Levine, 1977). The C3b is inactivated by cleavage to iC3b $\left(M_{\mathrm{r}} 175000\right)$ (Harrison \& Lachmann, 1980). C3b is subsequently degraded to $\mathrm{C} 3 \mathrm{c}$ and $\mathrm{C} 3 \mathrm{dg}\left(M_{\mathrm{r}} 43000\right)$ or C3d $\left(M_{\mathrm{r}} 33000\right)$ (Davis et al., 1984). With the exception of $\mathrm{C} 3 \mathrm{c}$, which is released into solution from the activating surface, these fragments all remain bound to the activating surface and are available as ligands for complement receptors.

Complement receptor type 1 (CR1), a 240000- $M_{\mathrm{r}}$ protein (Fearon, 1980), binds C3b and iC3b (Ross et al., 1983) and the activated form of the fourth component of complement (C4). The B-lymphocyte C3d receptor (CR2) is a molecule of $145000 M_{\mathrm{r}}$ (Iida et al., 1983) that mediates C3d and iC3b binding in B-lymphocytes (Micklem et al., 1984) and can also recognize C3b (Barel et al., 1981). Complement receptor type 3 (CR3) found on phagocytic cells is specific for $\mathrm{iC} 3 \mathrm{~b}$ and requires bivalent cations for activity (Ross et al., 1983). The protein corresponding to CR3 has been identified as the antigen termed ' $\mathrm{Macl}$ '
(Springer et al., 1979), on the basis of antibody inhibition (Beller et al., 1982) and by formation of a ternary iC3b-receptor-anti-Macl complex (Wright et al., 1983). This protein is a non-covalently linked heterodimer with subunits of $M_{\mathrm{r}} 165000$ and 95000 (Kurzinger et al., 1982) and is one member of the family of three homologous proteins named LFA-1, p150,95 and CR3, which share the same $95000-M_{\mathrm{r}}(\beta-)$ subunit (Sanchez-Madrid et al., 1983).

The receptors mediating the $\mathrm{C} 3 \mathrm{~d}$-binding activity of cultured monocytes (Inada et al., 1983) and polymorphonuclear leucocytes (Vik \& Fearon, 1985) have not been identified, although both anti-CR3 (Vargas et al., 1984) and an antibody directed against the common $\beta$-subunit of LFA-1, CR3 and p150,95 (Wright et al., 1984) have been reported to inhibit the monocyte receptor.

Although it is possible to study these receptors by soluble-ligand binding (Vik \& Fearon, 1985) or by rosetting of ligand-coated particles (Ross et al., 1983), the application of C3-fragment affinity chromatography has many advantages, especially when many receptors of overlapping specificity are involved (Micklem et al., 1984).

The present paper describes the isolation of the iC3b-fragment-binding proteins from spleen membranes and polymorphonuclear leucocytes. One of these proteins was identified, by using monoclonal antibodies, as p150,95, a homologue of LFA-1 and CR3.

\footnotetext{
Abbreviations used: PMN, human polymorphonuclear leucocytes; CR1, CR2 and CR3, complement receptor type 1, 2 and 3 respectively; phosphate-buffered saline, $8.2 \mathrm{~mm}-\mathrm{Na}_{2} \mathrm{HPO}_{4} / 1.5 \mathrm{~mm}-\mathrm{KH}_{2} \mathrm{PO}_{4} / 139 \mathrm{~mm}-\mathrm{NaCl} / 3 \mathrm{~mm}-\mathrm{KCl} / 1 \mathrm{~mm}-\mathrm{CaCl}_{2} / 1 \mathrm{~mm}-\mathrm{MgCl}_{2}, \mathrm{pH} 7.4 ;$ DFP, di-isopropyl phosphorofluoridate; PMSF, phenylmethanesulphonyl fluoride; SDS, sodium dodecyl sulphate; SBTI, soya-bean trypsin inhibitor; NP40, Nonidet P40; lysing buffer, $2 \%(\mathrm{w} / \mathrm{v})$ Nonidet $\mathrm{P} 40 / 10 \mathrm{mM}-\mathrm{Na}_{2} \mathrm{HPO}_{4} / 5 \mathrm{~mm}$-iodoacetamide/soya-bean trypsin inhibitor $(10 \mu \mathrm{g} / \mathrm{ml}) / 2 \mathrm{mM}-\mathrm{phenylmethane-}$ sulphonyl fluoride, $\mathrm{pH}$ 7.4. The nomenclature of complement components and of $\mathrm{C} 3$ and its fragments is as recommended by the World Health Organisation $(1968,1981)$.

‡ Present address and address for correspondence and reprint requests: Nuffield Department of Pathology, Level 1, John Radcliffe Hospital I, Headington, Oxford OX1 9DU, U.K.
} 


\section{METHODS AND MATERIALS}

\section{Spleen and PMN preparations}

Spleen membranes, which were a gift from Dr. S.-K. Law (Department of Biochemistry, University of Oxford, Oxford, U.K.), were prepared by homogenizing chopped human spleen suspended in $2.5 \%(\mathrm{v} / \mathrm{v})$ Tween 40 (Sigma)/ $10 \mathrm{~mm}$-Tris/HCl, pH 8, containing $10 \mathrm{~mm}-$ iodoacetamide, $2.5 \mathrm{~mm}$-DFP and $2 \mathrm{~mm}$-PMSF, with a Potter homogenizer (six strokes, $100 \mathrm{rev} . / \mathrm{min}$ ) on ice. This material was centrifuged at $3000 \mathrm{~g}$ for $20 \mathrm{~min}$ and the supernatant centrifuged at $40000 \mathrm{~g}$ for $20 \mathrm{~min}$. The second pellet was washed twice in $10 \mathrm{~mm}-\mathrm{Tris} / \mathrm{HCl}, \mathrm{pH} 8$, and stored at $-70^{\circ} \mathrm{C}$.

PMN were prepared from the blood of healthy donors by centrifugation over Histopaque (Sigma, Poole, Dorset, U.K.). The pellet was subjected to three washings with iso-osmotic $\mathrm{NH}_{4} \mathrm{Cl}$ to lyse the erythrocytes. The resulting cells were washed twice in phosphate-buffered saline to remove erythrocyte ghosts.

\section{Radioiodination}

PMN (107 cells) in $1 \mathrm{ml}$ of phosphate-buffered saline containing $0.5 \mathrm{mM}-\mathrm{CaCl}_{2}$ and $0.5 \mathrm{mM}-\mathrm{MgCl}_{2}$ were iodinated by using $1 \mathrm{mCi}$ of $\mathrm{Na}^{125}$ (Amersham International, Amersham, Bucks., U.K.) in an Iodogen (Pierce and Warriner, Chester, U.K.)-coated polyethylene tube for $10 \mathrm{~min}$ at room temperature. The cells were washed twice with phosphate-buffered saline and lysed by resuspension in lysing buffer for $20 \mathrm{~min}$ on ice.

The extract was centrifuged $(10000 \mathrm{~g}$ for $1 \mathrm{~min})$ and the supernatant applied to a Sepharose G-25 column (PD10; Pharmacia, Milton Keynes, Bucks., U.K.) equilibrated with $1 \%$ NP40/10 mM-sodium phosphate ( $\mathrm{pH} \mathrm{7.4)/}$ $0.5 \mathrm{~mm}-\mathrm{CaCl}_{2} / 0.5 \mathrm{~mm}-\mathrm{MgCl}_{2}$. The excluded material containing labelled membrane proteins was stored at $-70{ }^{\circ} \mathrm{C}$ before use. This material contained $0.15 \%$ of the initial ${ }^{125} \mathrm{I}$. Spleen membranes (10 $\mathrm{mg}$ of protein) in $0.5 \mathrm{ml}$ of $10 \mathrm{~mm}$-sodium phosphate, $\mathrm{pH} 7.4$, were iodinated in a similar way to cell suspensions, except that the iodination was terminated by the addition of $0.5 \mathrm{ml}$ of lysing buffer without washing. The membrane preparation was solubilized and gel-filtered exactly as described for the cells. This material contained $2.5 \%$ of the initial ${ }^{125} \mathrm{I}$.

\section{Affinity chromatography}

iC 3b-Sepharose was prepared by coupling purified humaniC 3 b to CNBr-activated Sepharose4B(Pharmacia) as described previously (Micklem et al., 1984). The ligand concentration was $2.2 \mathrm{mg}$ of $\mathrm{iC} 3 \mathrm{~b} / \mathrm{ml}$ of Sepharose.

The solubilized extracts were applied to an $\mathrm{iC} 3 \mathrm{~b}-$ Sepharose column $(2 \mathrm{ml})$ equilibrated with $1 \%$ NP40 in $10 \mathrm{~mm}$-sodium phosphate/ $1 \mathrm{mM}-\mathrm{CaCl}_{2} / 1 \mathrm{mM} \mathrm{MgCl}_{2}$ at $6 \mathrm{ml} / \mathrm{h}$. The column was washed with this buffer until the eluted radioactivity was at a minimum. The buffer was changed to $10 \mathrm{~mm}$-sodium phosphate, $\mathrm{pH} 7.4$, containing 2 mM-EDTA, and continued until the eluted radioactivity returned to the baseline value. The remainder of the iCb3-binding proteins were then eluted with an $\mathrm{NaCl}$ gradient (total volume $40 \mathrm{ml}$ ) up to $500 \mathrm{~mm}$ in the same buffer.

Immunoaffinity chromatography was performed by using $\mathrm{H} 52$ monoclonal antibody bound to $\mathrm{CNBr}$-activated Sepharose (a gift from Dr. S.-K. Law). Extracts were applied $(6 \mathrm{ml} / \mathrm{h})$ to the $\mathrm{H} 52$ column $(1 \mathrm{ml})$ equilibrated with $1 \%$ NP40/10 mM-sodium phosphate, $\mathrm{pH} 7.4$. The column was washed with this buffer and then with $200 \mathrm{~mm}-\mathrm{NaCl}$ in the same buffer. The bound proteins were eluted with $1 \%$ NP40/0.1 M-glycine/ $\mathrm{HCl}, \mathrm{pH} 2$.

\section{Immunoprecipitation}

Mouse monoclonal antibodies were obtained as follows: OKM1, which recognizes CR3 $\alpha$-chain (Wright et al., 1983), Ortho Diagnostics, High Wycombe, Bucks., U.K.; H52, an antibody directed against the common $\beta$-subunit of LFA-1, p150,90 and CR3 (Hildreth \& August, 1985), a gift from Dr. J. Hildreth, Johns Hopkins Medical School, Baltimore, MD 21205, U.S.A.; MHM24, an anti-(L-FA1 $\alpha$-chain) antibody (Hildreth et al., 1983), a gift from Professor A. McMichael, Nuffield Department of Surgery, John Radcliffe Hospital, Oxford, U.K.

Solubilized antigen preparations were incubated with antibodies at $5^{\circ} \mathrm{C}$ for $1 \mathrm{~h}$, and then rabbit anti-(mouse immunoglobulin) antibody bound to $\mathrm{CNBr}$-activated Sepharose $(0.1 \mathrm{ml}$ of a suspension containing $2.5 \mathrm{mg}$ of antibody bound to $50 \mu \mathrm{l}$ of gel) was added for a further $1 \mathrm{~h}$. The Sepharose was then washed twice with $1 \%$ NP40 in $10 \mathrm{~mm}$-sodium phosphate, $\mathrm{pH} 7.4$, twice with $200 \mathrm{mM}-\mathrm{NaCl}$ in the same buffer, and finally twice in $0.05 \%$ SDS. The absorbed proteins were eluted with $1 \%$ $\mathrm{NP} 40$ in $0.2 \mathrm{M}$-glycine $/ \mathrm{HCl}, \mathrm{pH} 2$. This material was analysed by SDS/polyacrylamide-gel electrophoresis.

\section{SDS/polyacrylamide-gel electrophoresis}

Samples were prepared by precipitation with $10 \%$ (w/v) trichloroacetic acid at $5^{\circ} \mathrm{C}$ by using $50 \mu \mathrm{g}$ of SBTI as carrier. The precipitate was washed with $5 \%$ trichloroacetic acid and twice with acetone before solubilization in $1 \% \mathrm{SDS} / 4 \mathrm{M}$-dithiothreitol/200 mMTris/ $\mathrm{HCl}, \mathrm{pH} 8$, at $80^{\circ} \mathrm{C}$ for $10 \mathrm{~min}$. Polyacrylamide-gel electrophoresis was performed by the method of Laemmli (1970) on a $6.5 \%$ gel. Marker proteins were detected with Coomassie Blue staining, and the gels dried for autoradiography with an intensifying screen (Du Pont, Stevenage, Herts., U.K.) exposed at $-70^{\circ} \mathrm{C}$.

\section{RESULTS AND DISCUSSION}

\section{iC3b-binding proteins from spleen}

As a source of complement receptors a membrane preparation from human spleen was labelled with ${ }^{125} \mathrm{I}$, solubilized in non-ionic detergent and applied to an iC $3 b-S e p h a r o s e ~ c o l u m n$ in a low-ionic-strength buffer containing $\mathrm{Ca}^{2+}$ and $\mathrm{Mg}^{2+}$ as described in the Methods and materials section. In order to elute CR3 specifically, after washing the unbound material from the column, EDTA was substituted for the bivalent cations without altering the ionic strength. This was followed by an $\mathrm{NaCl}$ gradient as described in the Methods and materials section to remove sequentially CR1 and CR2, together with any other $\mathrm{iC} 3 \mathrm{~b}$-binding proteins.

Fig. 1 shows an autoradiograph of a polyacrylamide gel of fractions of the material eluted from the column. At least six distinct radioactive peptides are visible. Four of these can be identified by size and elution conditions. The $240000-M_{\mathrm{r}}$ protein eluted at $10-30 \mathrm{mM}-\mathrm{NaCl}$ (tracks $6-9)$ is CR1. The $145000-M_{\mathrm{r}}$ protein eluted at 20-50 mM- NaCl (tracks 8-11) is CR2. The bands at $M_{\mathrm{r}}$ 150000 and 98000 eluted with EDTA (track 1) are the $\alpha$ and $\beta$-subunits of CR3.

The most prominent unidentified band in the EDTA eluate, of $M_{\mathrm{r}} 135000$, is in the expected position of the $\alpha$-chain of the third, relatively uncharacterized, member of the LFA1,CR3 family of antigens, which share a common $\beta$-subunit. This protein has been termed 'p150,95' (Sanchez-Madrid et al., 1983). $M_{\mathrm{r}}$ estimates, 


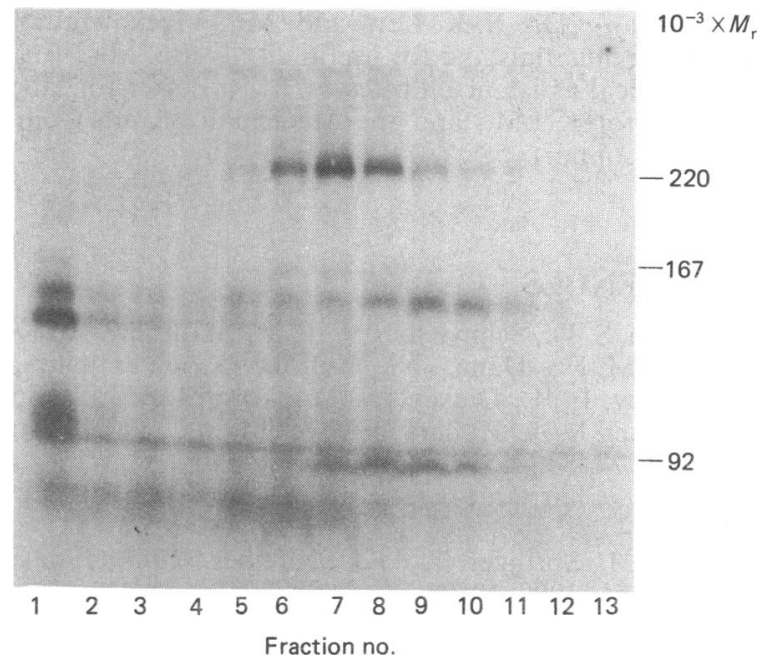

Fig. 1. Analysis of iC3b-binding proteins from labelled spleen membranes

Solubilized spleen membranes labelled with ${ }^{125} \mathrm{I}$ were applied to an iC $3 \mathrm{~b}-$ Sepharose column as described in the Methods and materials section. The column was washed until the eluted radioactivity was decreased to a constant level. The elution buffer was changed to 2 mM-EDTA and $4 \mathrm{ml}$ fractions were collected. After the peak of radioactivity had been eluted with EDTA, elution with a $40 \mathrm{ml}$ gradient of $0-500 \mathrm{~mm}-\mathrm{NaCl}$ in the same buffer was started. Samples $(2 \mathrm{ml})$ of each fraction were precipitated with trichloroacetic acid and analysed by SDS/polyacrylamide-gel electrophoresis. The Figure shows an autoradiograph of the fractions. Tracks $1-4$ are the EDTA elution. The $\mathrm{NaCl}$ gradient begins at track 5 . The $M_{\mathrm{r}}$ standards were: fibronectin, $M_{\mathrm{r}} 220000 ; \alpha_{2}$-macroglobulin, 167000; phosphorylase, $92000 . M_{\mathrm{r}}$ values for the sample proteins were calculated by interpolation on a semilogarithmic plot of the migration of standard proteins against $\boldsymbol{M}_{\mathrm{r}}$.

from SDS/polyacrylamide-gel electrophoresis, for these proteins vary. Although in the present paper the $M_{\mathrm{r}}$ estimates are different from those reported by SanchezMadrid et al. (1983), the nomenclature proposed by those workers is used here. The apparent $M_{\mathrm{r}}$ values we observe for these proteins are very similar to those reported by Anderson et al. (1984).

A suggestion, based on indirect evidence, that p150,95 might be responsible for $\mathrm{C} 3 \mathrm{~d}$ receptor activity in cultured monocytes (Wright et al., 1984) prompted a closer examination of the protein eluted with EDTA. The identification of this protein with a monoclonal antibody directed against the common $\beta$-subunit of LFA-1, CR3 and $\mathrm{p} 150,95$ is described below.

The other unidentified bands in Fig. 1 include a protein migrating at $90000 M_{\mathrm{r}}$, eluted with $15-40 \mathrm{mM}-\mathrm{NaCl}$ (tracks 7-10), and a faint band at $160000 M_{\mathrm{r}}$, eluted at $10-20 \mathrm{~mm}-\mathrm{NaCl}$ (tracks 6 and 7). These may be fragments of CR1 or CR2, although the $83000-M_{\mathrm{r}}$ active fragment of CR2 (Micklem et al., 1985) has the same ionic-strengthdependence of elution as intact CR2, suggesting that the unknown $90000-M_{\mathrm{r}}$ band is not a fragment of CR2 .

\section{iC3b-binding proteins from PMN}

Preliminary results indicated that the $135000-M_{\mathrm{r}}$ iC3b-binding protein eluted by EDTA was present in human peripheral-blood PMN extracts. As PMN are relatively easy to obtain, these cells were used in subsequent experiments as a more defined cell population.

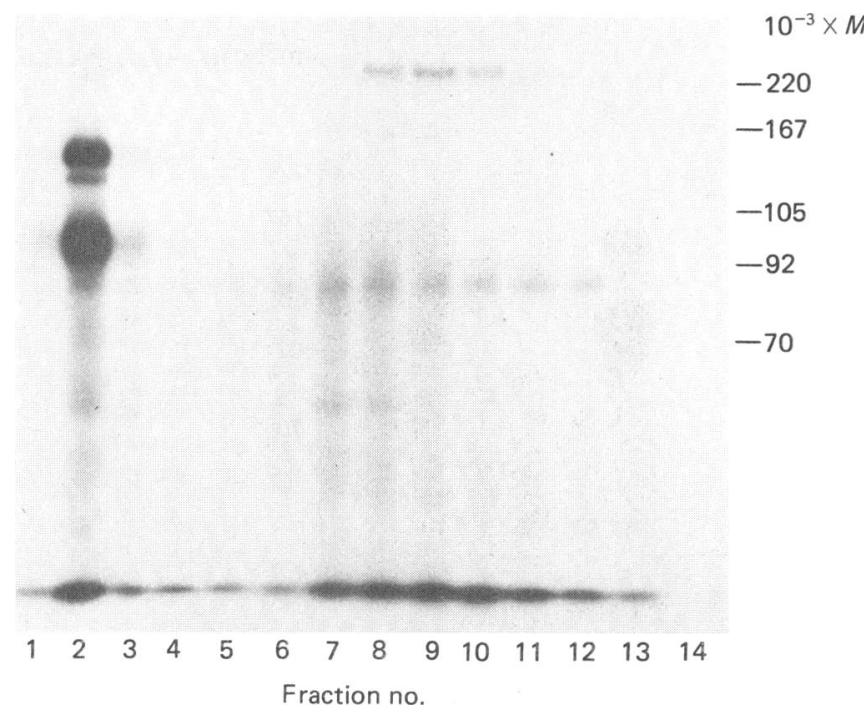

Fig. 2. Analysis of iC3b-binding proteins from labelled $P M N$

Solubilized PMN labelled with ${ }^{125}$ I were applied to an $\mathrm{iC} 3 \mathrm{~b}-$ Sepharose column as described in the Methods and materials section. The column was washed and eluted as described in the legend to Fig. 1. Tracks $1-4$ represent the elution with EDTA. The $\mathrm{NaCl}$ gradient begins at track 5 . The $M_{\mathrm{r}}$ standards were: fibronectin, $220000 ; \alpha_{2}$-macroglobulin, 167000; C3b, 105000 and 70000; phosphorylase, 92000.

Human PMN were prepared, labelled with ${ }^{125} \mathrm{I}$ and solubilized as described in the Methods and materials section. The extract was applied to an $\mathrm{iC} 3 \mathrm{~b}-$ Sepharose column. After washing the column the iC3b-binding proteins were eluted with EDTA and $\mathrm{NaCl}$ as described above. Fig. 2 shows an autoradiograph of the gel of material eluted with EDTA (tracks 1-4) and $\mathrm{NaCl}$ (tracks 5-14). The radioactive bands are similar to those given by the spleen preparation, with the exception of the absence of CR2, which is only found on B-lymphocytes (Nadler et al., 1981). The relative intensities of the bands are different from those given by the spleen material, the $\alpha$ - and $\beta$-subunits of CR 3 being especially prominent. The $90000-M_{\mathrm{r}}$ band is also more intense. The $135000-M_{\mathrm{r}}$ band eluted with EDTA is present at lower intensity, but is still readily detectable.

To identify positively the CR3 subunits and to investigate whether the $135000-M_{\mathrm{r}}$ band is the $\alpha$-subunit of p150,95, the PMN extract was passed down an anti-( $\beta$-subunit) antibody (H52) column to remove all $\beta$-subunit-containing molecules before chromatography on $\mathrm{iC} 3 \mathrm{~b}-\mathrm{Sepharose}$. In a reciprocal experiment the material that had passed through the iC $3 \mathrm{~b}$ column was applied to the anti-( $\beta$-subunit) antibody column.

PMN extract was applied to an H52-Sepharose column as described in the Methods and materials section. The material that did not bind was applied to an iC $3 b-$ Sepharose column as described above. Fig. 3 shows the EDTA eluates (tracks 1 and 2) from iC3b columns both before (track 1) and after (track 2) passing the starting material through an H52-Sepharose column. All three bands eluted by EDTA are removed by the H52-Sepharose column (compare track 1 with track 2), indicating that the two larger bands $(135000$ and $155000 M_{\mathrm{r}}$ ) are associated with the $98000-M_{\mathrm{r}} \beta$-subunit removed by the H52-Sepharose column.

The material from the original extract that bound to the H52-Sepharose is shown in Fig. 3, track 3. The 


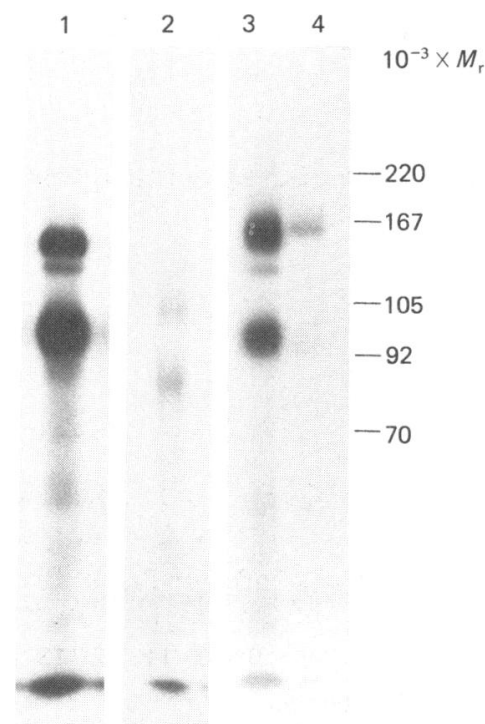

Fig. 3. Identification of iC $3 b-b i n d i n g$ proteins from PMN

Extracts $(1 \mathrm{ml})$ of ${ }^{125}$ I-labelled PMN were applied to an iC $3 b-S e p h a r o s e$ column as described in the Methods and materials section. Material eluted with EDTA (track 1) is shown. Identical PMN extracts were run on an H52Sepharose column $(1 \mathrm{ml})$ at $6 \mathrm{ml} / \mathrm{h}$ and the material passing through the column was applied to the $\mathrm{iC} 3 \mathrm{~b}-$ Sepharose column. The material eluted from iC3bSepharose with EDTA (track 2) is shown. The material binding to the H52-Sepharose column was eluted with pH 2 buffer and analysed (track 3 ). Similarly the material bound to $\mathrm{H} 52$ from a sample which had been pre-adsorbed with iC3b-Sepharose was analysed (track 4). The standards were as described in the legend to Fig. 2.

material that binds to $\mathrm{H} 52$ after $\mathrm{iC} 3 \mathrm{~b}-$ Sepharose chromatography, that is, material which ran through the $\mathrm{iC} 3 \mathrm{~b}-$ Sepharose column, is shown in track 4. The H52 column binds all three $\beta$-subunit-containing proteins (track 3 ) in the original extract (the 165000- $M_{\mathrm{r}}$ LFA1 $\alpha$-and the $150000-M_{\mathrm{r}} \mathrm{CR} 3 \alpha$-subunits are poorly resolved on this gel). After passing the PMN extract down an iC3b-Sepharose column, only LFAl remains to be bound to the H52 column (track 4).

These results show that the three bands eluted from the $\mathrm{iC} 3 \mathrm{~b}$ column by EDTA are the subunits of CR3 and the protein termed p150,95.

The significance of the binding of p150,95 to iC3b is not at present known. It is not known if it acts as a receptor for $\mathrm{iC} 3 \mathrm{~b}$-coated particles, or perhaps for soluble C3 fragments Cole et al. (1985) have reported a C3b-binding protein that does not mediate rosetting with C3b-coated particles, whereas Vik \& Fearon (1985) have described a receptor activity on PMN which appears to bind soluble $\mathrm{C} 3$ fragments but does not mediate rosetting (PMN do not rosette with C3d-coated erythrocytes). p150,95 may be associated with the cultured monocyte C3d receptor (Inada et al., 1983), which can apparently be inhibited by an anti-( $\beta$-chain) monoclonal antibody (Wright et al., 1984).

The $90000-M_{\mathrm{r}}$ iC3b-binding protein may be associated with the receptor for soluble C3d on PMN reported by Vik \& Fearon (1985), which is not dependent on the presence of bivalent cations for activity.
We thank Dr. S.-K. Law and Mr. Vivek Malhotra for providing materials and for useful discussion, Miss B. Moffatt for technical assistance, Professor R. R. Porter for laboratory facilities for K.J.M., and the Medical Research Council for financial support.

\section{REFERENCES}

Anderson, S. D., Schmalstieg, F. C., Arnaout, M. A., Kohl, S., Tosi, M. F., Dana, N., Buffone, G. J., Hughes, B. J., Brinkley, B. R., Dickey, W. D., Abramson, J. S., Springer, T., Boxer, L. A., Hollers, J. M. \& Smith, C. W. (1984) J. Clin. Invest. 74, 536-551

Barel, M., Charriaut, C. \& Frade, R. (1981) FEBS Lett. 136, 111-114

Beller, D. I., Springer, T. A. \& Schreiber, R. D. (1982) J. Exp. Med. 156, 1000-1009

Cole, J. E., Houslay, G. A., Dykman, T. R., MacDermott, R. P. \& Atkinson, J. P. (1985) Proc. Nat. Acad. Sci. U.S.A. 82, 859-863

Davis, A. E., Harrison, R. A. \& Lachmann, P. J. (1984) J. Immunol. 132, 1960-1966

Ehlenberger, A. G. \& Nussenzweig, V. (1971) J. Exp. Med. 145, 357-371

Fearon, D. T. (1980) J. Exp. Med. 152, 20-30

Fearon, D. T. \& Wong, W. (1983) Annu. Rev. Immunol. 1, 243-271

Harrison, R. A. \& Lachmann, P. J. (1980) Mol. Immunol. 17, 9-20

Hildreth, J. E. K. \& August, J. T. (1985) J. Immunol. 134, 4272-3280

Hildreth, J. E. K., Gotch, F. M., Hildreth, P. D. K. \& McMichael, A. J. (1983) Eur. J. Immunol. 13, 202-208

Iida, K., Nadler, L. \& Nussenzweig, V. (1983) J. Exp. Med. 158, 1021-1033

Inada, S., Brown, E. J., Gaither, T. A., Hammer, C. H., Takahashi, T. \& Frank, M. M. (1983) Proc. Natl. Acad. Sci. U.S.A. 80, 2351-2355

Kurzinger, K., Ho, M.-K. \& Springer, T. A. (1982) Nature (London) 296, 668-670

Laemmli, U. K. (1970) Nature (London) 227, 680-685

Law, S.-K. \& Levine, R. P. (1977). Proc. Natl. Acad. Sci. U.S.A. 74, 2701-2705

Micklem, K. J., Sim, R. B. \& Sim, E. (1984) Biochem. J. 224, 75-86

Micklem, K. J., Sim, E \& Sim, R. B. (1985) FEBS Lett., in the press.

Nadler, L. M., Stashenko, P., Hardy, R., van Agthoven, A., Terhorst, C. \& Schlossman, S. F. (1981) J. Immunol. 126, 1941-1947

Ross, G. D., Newman, S. L., Lambris, J. D., Devery-Pocius, J. E., Cain, J. E. \& Lachmann, P. J. (1983) J. Exp. Med. 158, 334-352

Sanchez-Madrid, F., Nagy, J. A., Robbins, E., Simon, P. \& Springer, T. A. (1983) J. Exp. Med. 158, 1785-1803

Springer, T., Galfre, G., Secher, D. S. \& Milstein, C. (1979) Eur. J. Immunol. 9, 301-306

Vargas, I., Gaither, T. A., Hammer, C. H., O’Shea, J. \& Frank, M. M. (1984) Fed. Proc. Fed. Am. Soc. Exp. Biol. 43, 1457

Vik, D. P. \& Fearon, D. T. (1985) J. Immunol. 134, 2571-2579

Weigle, W. O., Goodman, M. G., Morgan, E. L. \& Hugli, T. E. (1983) Springer Sem. Immunpathol. 6, 173-194

World Health Organisation (1968) Bull. WHO 39, 935-936

World Health Organisation (1981) Bull. WHO 59, 489-490

Wright, S. D., Rao, P. E., VanVorrhis, W. C., Craigmyle, L. S., Iida, K., Talle, M. A., Westburg, E. F., Goldstein, G. \& Silverstein, G. (1983) Proc. Natl. Acad. Sci. U.S.A. 80, 5699-5703

Wright, S. D., Licht, M. R. \& Silverstein, S. C. (1984) Fed. Proc. Fed. Am. Soc. Exp. Biol. 43, 413 